\title{
ETHICS AND NATURAL SCIENCE THROUGH PAUL RICOEUR'S HERMENEUTICS
}

Paul Ricoeur's well-known perspective on philosophical hermeneutics could also be applied in the understanding of natural sciences. This should resemble dialectic between explanation and understanding, which would enable the kind of objectivity that is claimed in all areas of science. Therefore, science could be viewed as an epistemological activity focused on modeling and confirmation of theory, as well as a theoretical practice that operates alongside other technological, ethical, and political practices. From epistemological perspective we will look for a role of hermeneutics in natural science. Explanation and understanding connect natural science with hermeneutics. Through a narrative position of Ricoeur's hermeneutics, we can understand the connection between science and its responsibility.

Keywords: Natural science, hermeneutics, Paul Ricoeur, narrative, subject of responsibility.

\section{Introduction}

In 1996, physicist Alan Sokal published an article in Social Text, a popular cultural studies' magazine, which was primarily a hoax. "The article, entitled 'Transgressing the Boundaries: Toward a Transformative Hermeneutics of Quantum Gravity', is abundant in absurdities and blatant non-sequiturs. In addition, it asserts an extreme form of cognitive relativism: after mocking the old-fashioned 'dogma' that 'there exists an external world, whose properties are independent of any individual human being and indeed of humanity as a whole', it proclaims categorically that 'physical 'reality', no less than social 'reality', is at bottom a social and linguistic construct" [1, pp. 1-2]. The article was not only published, but included in a special issue, which was meant to chastise scientists who did not accept postmodernist understanding of science as a social and linguistic construct. Even though the article names hermeneutics more or less only in the title, it is clear whom it is criticizing. Sokal is convinced that relativism in natural sciences, which is defined by postmodernist thinkers who claim a hermeneutic approach, opens a door to religious obscurities and pseudo sciences [2, p. 101].

The above-cited book, which was based on the article, explains, "We make no claim to analyze postmodernist thought in general; instead, our aim is to draw attention to a relatively little-known aspect, namely the repeated abuse of concepts and terminology coming from mathematics and physics" [1, p. 4]. Humanities are therefore supposed to be abusing concepts in mathematics and physics as well as obscuring the basic scientists' mission: to research and test through well planned and controlled experiments. They are mostly bothered by the complicated language and intricate manipulation of terminology, which is taken from natural sciences. "Our aim here is to stimulate a critical attitude, not merely towards certain individuals, but towards a part of the intelligentsia (both in the United States and in Europe) that has tolerated and even encouraged this type of discourse" [1, p. 7].

Not a very encouraging start of a research, which aims to show how necessary hermeneutics is to modern natural sciences. Thankfully, the authors did not include Paul Ricoeur with their postmodernist thinkers, because our thesis, which says that hermeneutics is a step in scientific investigation, comes from the thought of this twentieth century French philosopher. Many people credit him with setting the foundations of hermeneutic philosophy, which is today spread in Europe as well as United States [3]. Our aim is to show that P. Ricoeur's approach is appropriate both for questions in humanities, such as the influence of science on society and scientists' responsibility, as well as natural sciences themselves, because they always need to develop new models, form theories, and explain the achieved results.

\footnotetext{
* Janez Vodicar

Faculty of Theology, University of Ljubljana, Slovenija

E-mail: janez.vodicar@guest.arnes.si
} 


\section{Ricoeur's Approach to Hermeneutics}

Ricoeur began his philosophical journey in the spirit of Husserl's phenomenology. For our research, it is important that the leading thought in Ricoeur's philosophy acknowledges and faces the boundaries of one's own understanding. He does not see that as an obstacle, but as a catalyst for creative imagination. We do not have a direct access to the knowledge of ourselves; we understand and place ourselves through meanings that we have to interpret [4, p. 221]. Through speaking, we become aware of consciousness and also form it. Discourse, which Ricoeur accepts from Beneveniste, introduces a semiotic function of language, based on the sign, a semantic function that originates from the sentence and which introduces the expression of an event, which is otherwise unnoticed by structural analysis [5, p. 25]. For us it is important that Ricoeur begins to explore written text in his development of hermeneutics. An event that is lost in speech, is in written text distanced from the original event, but precisely because of that allows the reader to give it life again. Text allows a "threefold autonomy: with respect to the intention of the author; with respect to the cultural situation and all the sociological conditions of the text production; and finally, with respect to the original addressee" [6, p. 91]. This threefold autonomy of the text does not mean that the author is lost. What the text tells me now is more than the author intended to say, because the process of exegesis is needed, through which the readers bring their own views [6, p. 201]. Here, we do not mean some relativism of interpretations as criticized by Sokal, even though multiple interpretations of the text are possible. Still, it is always possible to argue for a more correct interpretation, which can be double checked, because we have now established an objective field of research - inclusion of discourse into the text. Every text has limitations in interpretation however [6, p. 213].

Ricoeur's dedication to hermeneutics is, aside from his search for proper interpretation, also seen in his search for a broader field in which an individual is able to create new meanings. Man is always born into an environment, which is why cannot be aware of himself unless he becomes one with the meaning, which is first found outside of him [4]. If philosophy has its sources and presuppositions which it must follow and also be aware of, it cannot be caught in some totality in itself. "Like Derrida, Ricoeur thinks that objectifying methods are an indispensable 'guardrail' to interpretation, a necessary protection against lapsing into an 'anything goes' attitude. But he also thinks they should not be the tail wagging the dog. To make the text an object to be explained with the help of some method for the sake of the objectivism in interpretation and to identify this task as the whole hermeneutical task is to treat the text like 'a cadaver handed over for autopsy' and to act 'as though one were to give the funeral eulogy of someone yet alive" [7, p. 68]. Thus we rise above the division between explaining and understanding, which was introduced by Dilthey. If the former is reserved for natural science and the latter for humanities, Ricoeur finds that it is in the text where this division is bridged. "I am most suspicious of the old opposition between understanding, which would be the portion of the first science, and explanation, which would be the lot of the second. If the communication of past heritages takes place under the condition of distanciation and objectification, then explanation is a necessary step for understanding. We always explain in order to understand better. A text must be explained in its internal structure before being understood in its relation to the interest it arouses and to which it responds" [8, p. 264]. Through interpretation and explanation of a text, we look for validation of our guess. This happens, for example, through the analysis of linguistic structure, style, author's history, etc. "Validation, which Ricoeur is careful to distinguish from verification in a positivist sense, involves weighing an initial guess against other possible guesses, and selecting the most probable one as the best interpretation" [2, p. 73]. We can only understand through explanation. Hermeneutic circularity weaves between the whole and its parts, as well as individual parts and their whole in research, as we are searching for a new meaning. The entire process, which takes place from a methodically influenced explanation to the non-methodical moment of understanding, marks Ricoeur's hermeneutics [2, p. 85]. This understanding must lead to appropriation, because only then the discourse becomes an event again and is therefore free from its initial connection to the author and causes a change in the reader [9, pp. 33-35]. This moment of appropriation is important in the communication of scientific discoveries, because without it, it remains knowledge, trapped in a laboratory [5, pp. 201-202]. Ricoeur stands for objective explanation, which is an ideal in science. However, he insists that any objectivization is connected to an individual experience. "I have always argued in favor of a coordination between (experienced) understanding and (objective) explanation. I want to explain in order to better understand" [10, p. 126].

\section{Natural Sciences and Hermeneutics}

If we can learn anything from Ricoeur's theory, it is that hermeneutics needs interpretation. There is no direct and unbiased understanding, which is why we need explanation that can lead to better understanding, which is also the goal of scientific field. However, when we use hermeneutics in science, we have to be mindful of relativism, which we have mentioned at the beginning with Sokal's help. When we move past Descartes' and Bacon's views of science, hermeneutics leads to a slippery slope of uncertainty, which introduces numerous variables into practical empirical experimentation and creation of laws. At the very beginnings of modern empirical science, F. Bacon reminded us of four types of idols, and only after we clear our minds of them, can we begin a true scientific procedure. The development of positivism, which followed this demand, developed this outlook 
as possibly an increasing division between humanities and natural sciences, which is summarized by Dilthey in his step-by-step differentiation between understanding and explanation.

Despite exaggeration, which some postmodernist thinkers introduce to interpretation of natural sciences, even Sokal and Bricmont agree that hermeneutic critique of naive modernism is needed. They also accept interdisciplinary work, but with clear boundaries and jurisdictions in methodology of each scientific field [1, pp. 183-185]. If we begin with the description of the three possible primary attitudes towards science, as defined by Ian Barbour, and as have been confirmed through history, which are positivism, instrumentalism, and idealism [11, p. 162], we can say that we have largely moved past the naïve positivistic approach, in which scientists are supposed to be some "labor-saving mental devices for classifying observations". Instrumentalism says that a scientist is the person who thinks of and prepares an experiment. Thus he is responsible for "(a)calculating devices for making accurate predictions, (b) organizing guides for directing further experimentation, and (c) practical tools for achieving technical control" [11, p. 165]. The scientist then already needs imagination, which only serves as 'useful fictions', but it will be difficult for the scientist to decide which of the theories was more accurate once he gathers all his data [2, p. 4). Scientific theories for the idealist are "entirely imposed by the mind on the chaos of sense-data" [11, p. 166]. This is a clear opposition to positivism, because this theory says that atom as such was not discovered, but devised as a mental construct. However, such approach to science cannot explain why certain theories explain our empirical data better than others, and why not all explanations of natural phenomena are equally correct [12].

Barbour follows critical realism, through which he intends to fix all the problems of the above-mentioned approaches. "Against the positivist, the realist asserts that the real is not the observable. Against the instrumentalist, he affirms that valid concepts are true as well as useful. Against the idealist, he maintains that concepts represent the structure of events in the word. The patterns in the data are not imposed by us, but originate at least in part in objective relationships in nature. The object, not the subject, makes the predominant contribution to knowledge. Hence science is discovery and exploration, not just construction and invention" [11, pp. 168-169]. This does not prove that hermeneutics is necessary, but it can be claimed that Barbour confirms the need for interpretation, which does not deny the objectivity of scientific experimentation. But there are also no uninterpreted facts [2, p. 4]. The need for interpretation makes scientific language symbolic, and thus we enter the area of many different interpretations of the same sign or fact. But since this means polysemy, Ricoeur claims that hermeneutics is needed. This is not just mere poeticism, which freely creates new meanings, as criticized by Sokal and Bricmont, but a methodologically difficult process which is subject to certain laws, as shown by Ricoeur in his discussion on metaphor [13].
Many scientists would oppose this, saying that they already have epistemology in their own scientific field, which clearly defines what and how can be researched and how to interpret it. They do not require any metaphysical poetic approaches, which would use natural sciences as an excuse to creating new metaphors [1, p. 187]. Wentzel van Huyssteen, who follows Barbour, claims that hermeneutics and epistemology are organically interconnected in science. All language is metaphorical and we need hermeneutics to use it correctly in epistemological approach [14, p. 158]. On the other hand, he warns that opposition of postmodernist indubitable foundations for knowledge can lead to the loss of rationality, which is the base of any argumentation.

\section{Hermeneutics and Science}

P. Ricoeur was always against the confusion of fields [10, p. 14]. According to him, separation of fields not only prevents irresponsible, oversimplified discussions, which make no new discoveries, but is able to produce reasons for new meanings to be developed. Variety, as we saw in chapter one, leads to a necessity for interpretation, and thus promotes thoughtfulness and creativity, which drives new research. Just as new text initially distanced the reader, a meeting of different scientific fields and views is the distanciation that requires interpretation. Through the process of distanciation in science we are first given the option to conduct research. It is a definition and a limitation of the field of research. At the same time, we allow ourselves to think about this objectively and in a way - at least partially - free ourselves from presuppositions that we bring into research. This also triggers the need for interpretation, because distanciation brings unrest to accepted concepts [15, p. 44]. However, "hermeneutics proceeds from a prior understanding of the very thing that it tries to understand by interpreting it” [16, p. 352]. We must know ahead of time that we can clear up all confusion and false understandings, but we will have to keep looking for proper answers and solutions through public interpretation and by following the laws of hermeneutic cycle.

Interdisciplinary cooperation can in itself give us an opportunity for distanciation and demand new understanding. Finally, appropriation of a new meaning, truth, or discovery, is an end goal of any interpretation, whether of a text or of scientific data. "Finally, insofar as the appropriation of the world which the text unfolds may result in an expansion of the horizons of consciousness, the process of interpretation creates the possibility for a critique of the egoistic illusions and ideological distortions of the subject" [17, p. 67]. This critique of narrow consciousness, which occurs in the process of interpretation and allows for a new outlook, opens a new creative potential for science as well, which cannot happen if it remains limited to empirical research in a sterile laboratory. Educational role of a scientist, as has been required by the educational system since the enlightenment is: 
the expansion of the horizons of consciousness, which leads to improved life style of an individual and society [18, pp. 184-186].

\section{Conclusion}

Sokal and Bricmont conclude their critique of postmodernist abuse of science with the role of politics in this phenomenon, which is seen both in its support of relativism and in its ability to change it [1, pp. 197-205]. We conclude that the use of Ricoeur's hermeneutics helps raise responsibility of the society to science and of scientists to the society. As Ricoeur stressed in his conversation with Changeux, man cannot be divided into a scientist, normal human being, or a religious person, because it is impossible to pluck him out of his environment and away from suppositions that help him make decisions and choices; instead he must be encouraged to better explain his actual state, in order to gain a better understanding [10, pp. 125-126]. He also cites examples of scientists who claim that neurons think. It is an example of typical reduction, which abuses science and thus causes unnecessary conflicts. With his critical reading Ricoeur binds both scientists and philosophers, to find the best possible answers for the wellbeing of humanity through confrontation with each other. He asserts that they will use their authority, which he sees as a necessary realm of humanity, responsibly in order to promote and educate people to take their responsibility too.

\section{References:}

[1] SOKAL, A. BRICMONT, J.: Fashionable Nonsense Postmodern Intellectuals' Abuse of Science. New York: Picador, 1998. ISBN 0-31219445-1.

[2] REYNHOUT, K. A.: Interdisciplinary Interpretation: Paul Ricoeur and the Hermeneutics of Theology and Science. Lanham: Boulder : New York: Lexington Books, 2013. ISBN 978-1-4985-1587-0.

[3] REAGAN, CH. E.: Paul Ricoeur His Life and his Work. Chicago, London: The University of Chicago Press, 1996. ISBN 0-22670603-6.

[4] RICOEUR, P.: The Conflict of Interpretations. Essays in Hermeneutics. Evanston: Northwestern University Press, 1974. ISBN 978-08264-7709-5.

[5] VAN DEN HENGEL, J. W.: The Home of Meaning. The Hermeneutics of the Subject of Paul Ricoeur. Washington: University Press of America, 1982. ISBN 0-8191-2603-9.

[6] RICOEUR, P.: Hermeneutics and the Human Sciences: Essays on Language, Action and Interpretation. Cambridge: Cambridge University Press, 1981. ISBN 1-107-14497-3.

[7] WESTPHAL, M.: Whose Community? Whose Interpretation? Grand Rapids: Baker Academic, 2009. ISBN 978-0-8010-3147-2. See e.g.: JUROVA, J.: On Etzioni's Concept of a Responsive Community. European J. of Science and Theology, vol. 12, No. 3, 2016, 71-80. ISSN 1841-0464.

[8] RICOEUR, P.: Ethics and Culture: Habermas and Gadamer in Dialogue. In: Political and Social Essays. Ed. David Stewart and Joseph Bien. Athens: Ohio University Press, 1974. ISBN 0-8214-0169-6.

[9] This hermeneutic procedure applies not only to texts but also to visual phenomena. See: KLUN, B.: Distinction by Marion between Idol and Icon and the Question of Hermeneutics (in Slovenian). Bogoslovni vestnik - Theological Quarterly, vol. 76, No. 1, 2016, 25-35. ISSN 0006-5722

[10] CHANGEUX, J.-P., RICOEUR, P.: What Makes Us Think? A Neuroscientist and a Philosopher Argue about Ethics. Princeton: Princeton University Press, 2002. ISBN 978-0-691-09285-0. On this topic, see also: KONDRLA, M., PAVLIKOVA, M. From formal ethics to existential ethics. European J. of Science and Theology, vol. 12, No. 3, 2016, 101-111. ISSN 1841-0464. KONDRLA, P., KRALIK, R.: Authentic being and moral conscience. European J. of Science and Theology, vol. 12, No. 4, 2016, 155-164. ISSN 1841-0464. VALCO, M., KRALIK, R. \& BARRETT, L.: Moral implications of Augustine`s philosophical and spiritual journey in his confessions. Communications - Scientific Letters of the University of Zilina, vol. 17, No. 2, 2015, 103-108. ISSN 1335-4205.

[11] BARBOUR, I. G.: Issues in Science and Religion. New York: Prentice-Hall, 1966. ISBN 0-334-00737-2.

[12] Compare with: HANES, P. \& MASARIK, M.: Complementarity of Science and Theology. European J. of Science and Theology, vol. 12, No. 6, 2016, 5-20. ISSN 1841-0464.

[13] RICOEUR, P.: The Rule of Metaphor. Toronto, Buffalo, London: University of Toronto Press, 2000. ISBN 0-8020-6447-7.

[14] VAN HUYSSTEEN, W. J.: Theology and the Justification of Faith: Constructing Theories in Systematic Theology. Grand Rapids : Eerdmans, 1989. ISBN 0-8028-0266-0.

[15] RICOEUR, P.: Interpretation Theory: Discourse and the Surplus of Meaning. Fort Worth: Texas Christian University Press, 1976. ISBN 0-912646-59-4. 
[16] RICOEUR, P.: The Symbolism of Evil. Boston: Beacon Press, 1967. ISBN 0-8070-1567-9.

[17] THOMSON, J. B.: Critical Hermeneutics. A study in the thought of Paul Ricoeur and Jurgen Habermas. Cambridge: Cambridge University Press, 1995. ISBN 978-0-521-27666-5.

[18] The roots of this idea in the European context go all the way to the Humanists and the reformers in the $16^{\text {th }}$ century. On this topic, see: VALCO, M.: The roots and nature of Luther's theological understanding of 'Missio Dei' in the Context of Reformation agenda. European J. of Science and Theology, vol. 12, No. 4, 2016, 181-188. ISSN 1841-0464. 